\title{
A new type of Kranz anatomy in Asteraceae
}

\author{
Guadalupe Peter $^{\mathrm{A}, \mathrm{C}}$ and Liliana Katinas ${ }^{\mathrm{B}}$

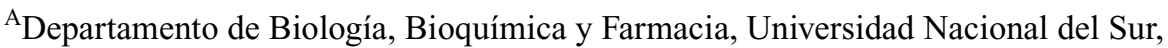 \\ San Juan 670 (8000) Bahía Blanca, Argentina. \\ ${ }^{B}$ División Plantas Vasculares, Museo de La Plata, Paseo del Bosque s/n (1900) La Plata, Argentina. \\ ${ }^{\mathrm{C}}$ Corresponding author; email: gpeter@criba.edu.ar
}

\begin{abstract}
The anatomical structure of the leaves and stems of the 13 species of Isostigma (Asteraceae: Heliantheae) has been examined by using light microscopy. All species of Isostigma have Kranz anatomy in their leaves, containing one or more Kranz units $(=\mathrm{KU}$, the unit constituted by the vascular bundle/s, the parenchyma sheath and the surrounding mesophyll). It is demonstrated that there are the following two different types of Kranz anatomy in leaves of Isostigma: (1) Eryngiophyllum type, with one KU per leaf and with sclerenchyma tissue (I. brasiliense, I. cordobense, I. crithmifolium, I. dissitifolium, I. peucedanifolium, I. riedelii, I. simplicifolium and I. speciosum); and (2) Isostigma type, with more than one KU per leaf, without sclerenchyma tissue (I. acaule, I. herzogii, I. hoffmannii, I. molfinianum and I. scorzoneraefolium). The stems of all 13 species of Isostigma show also Kranz anatomy, without variation among species. Until the present, the Eryngiophyllum and the Atriplicoid types were the only reported for Asteraceae. The Isostigma type is a new type for the family, characteristic of plants growing in humid places. The following evolutionary sequence of Kranz anatomy is hypothesised: Atriplicoid-Isostigma-Eryngiophyllum where numerous KUs become continuous to reach a unique, compound KU.
\end{abstract}

\section{Introduction}

The $\mathrm{C}_{4}$ photosynthetic syndrome consists of anatomical, physiological and biochemical components, all of which must be present to facilitate proper functioning of the $\mathrm{CO}_{2}$-concentrating mechanism that $\mathrm{C}_{4}$ plants possess in addition to the Calvin-Benson $\left(\mathrm{C}_{3}\right)$ pathway of carbon fixation (Björkman 1973; Fisher et al. 1997).

The Kranz anatomy is intimately linked to the $\mathrm{C}_{4}$ photosynthesis. Haberlandt $(1882,1914)$ used the term Kranz to refer to the wreath of radially arranged mesophyll cells surrounding the leaf bundle sheath. Currently, the term is applied to both the enlarged chloroplast-rich bundle-sheath cells (Kranz cells) and to the entire suite of distinctive structural characteristics (Kranz anatomy) (Dengler and Nelson 1999). Variation in Kranz anatomy in genera and species led to the establishment of different Kranz types as shown for example in the classifications of Johnson and Brown (1973), Brown (1975), Carolin et al. (1975) and Pyankov et al. (2001).

Knowledge of the presence or absence of Kranz anatomy has been recognised of taxonomic, phylogenetic, ecological and economic interest in plant families and genera. Therefore, the different aspects of this photosynthetic pathway were extensively analysed, focusing principally on Poaceae (e.g. Johnson and Brown 1973; Zuloaga et al. 1989) within the Monocotyledonae and Chenopodiaceae (e.g.
Carolin et al. 1975, 1978) within the Dicotyledonae. However, these types of studies in Asteraceae are not extensively developed. Some representative work has been done by Schöch (1971), Brown (1975), Smith and Turner (1975), Sánchez et al. (1986, 1987), Moore et al. (1987), Sarmiento et al. (1989, 1995), Araus et al. (1990), Petenatti and Del Vitto (2000) and Peter (2001), with only a few of them dealing with anatomy.

Species of Asteraceae that possess the high ${ }^{13} \mathrm{C}:{ }^{12} \mathrm{C}$ ratio typical of Kranz syndrome were found in only two tribes, Heliantheae and Helenieae (Smith and Turner 1975), with 150 species in five genera $\left(2 \%\right.$ of all $\mathrm{C}_{4}$ and $1.3 \%$ in the family) (Sage et al. 1999). In the Helenieae only two genera, Flaveria and Pectis, have $\mathrm{C}_{4}$ anatomy. In the Heliantheae, one species of Parthenium was found $\mathrm{C}_{3}-\mathrm{C}_{4}$ intermediate (Moore et al. 1987), whereas $\mathrm{C}_{4}$ syndrome is exclusive of three genera belonging to the subtribe Coreopsidinae, namely Chrysanthellum (=Eryngiophyllum; 13 species from Mexico to South America, Galapagos, Africa and India), Isostigma (c. 13 South American species) and Glossocardia (=Glossogyne, Guerreroia, Neuractis; 12 species from Asia and Australia) (Smith and Turner 1975; Kellogg 1999; Sage et al. 1999). These three genera, with the addition of Diodontium and Trioncinia (both genera of Australia), are recognised as the Chrysanthellum group (Karis and Ryding 1994). 
Prior to this study, the only published $\mathrm{C}_{4}$ anatomical studies of some of the above mentioned genera were performed by Brown (1975) and Sánchez et al. $(1986,1987)$. Brown (1975) established the Eryngiophyllum type for genera of Chenopodiaceae and Asteraceae, characterised by continuous single layers of mesophyll and parenchyma sheath beneath the epidermis. Almost at the same time, Carolin et al. (1975) assigned other new type names for the same genera of Chenopodiaceae considered by Brown (1975). The genera of Asteraceae examined by Brown (1975) were Chrysanthellum, Eryngiophyllum (currently Chrysanthellum), Flaveria, Glossocardia, Glossogyne (currently Glossocardia), Isostigma and Pectis. In his study, Brown (1975) did not specify which species of each genus were analysed. Furthermore, Sánchez et al. (1986) found another $\mathrm{C}_{4}$ anatomy in the leaves of Chrysanthellum argentinum and $C$. tuberculatum (considered synonyms of C. indicum DC. var. afroamericanum B.L.Turner by Turner 1988), without mentioning or establishing a Kranz type for them. Both species show the typical parenchyma sheath of cells with large chloroplasts and a mesophyll layer surrounding each vascular bundle. In addition, Kranz structure in stems of both species of Chrysanthellum was found (Sánchez et al. 1987). It is interesting to note that there is not a strict correlation between the presence of Kranz anatomy in the leaves and stems, since for example species of the genus Pectis (Asteraceae: Helenieae) possess Kranz anatomy exclusively in leaves (Sánchez et al. 1987).

The South American genus Isostigma, considered the most closely related genus to Chrysanthellum (Ryding and Bremer 1992; Karis and Ryding 1994), is a little-studied assemblage of c. 13 species (Sherff 1926; Sherff 1931; Cabrera 1959) of perennial herbs and subshrubs of north-eastern and central Argentina, southern and eastern Brazil, south-eastern Bolivia, Paraguay and Uruguay. Some species are known from the type collection only; many are quite localised, occurring only in the mountain ranges of central Argentina. With relatively few species, Isostigma grows in different habitats such as dry, subhumid and humid places. A revision of the genus Isostigma in progress (G. Peter, unpubl. data), led to focus our attention to the particular structure of leaves. Although Brown (1975) reported the Eryngiophyllum type for leaves of this genus, we noted variation among species in their Kranz anatomy. The main objective of the present study was to investigate this variation.

\section{Material and methods}

Leaves and stems of the 13 species of Isostigma were obtained from herbarium specimens. Localities and vouchers are listed in the Appendix. Material of most species was submerged in ethyleneglycol for 6 days (Schwabe 1961), then fixed in FAA (formalin-acetic acid-alcohol) and processed by usual techniques of paraffin infiltration. Serial transverse sections were cut $10 \mu \mathrm{m}$ thick with a Minot microtome and stained with Safranin for $8 \mathrm{~h}$ and Fast Green for
$25 \mathrm{~s}$; sections were mounted in Canada balsam. Free-hand sections of leaves and stems of all species were also cut, some sections were cleared and stained with Safranin while the rest were left unstained and mounted in glycerin jelly. Whole leaves and leaflets were cleared according to Strittmatter (1973).

Light microscopy observations were carried out on a Leitz SM Lux with camera lucida technique. Selected light microscopy images were transferred electronically from the microscope to the computer using the Photo Express version 1.0 software.

Some terms employed in the Results and Discussion are here defined:

Kranz unit (KU): is constituted by the vascular bundle/s enclosed in the parenchyma sheath and the surrounding mesophyll. Sánchez et al. (1986) referred to these units as 'unidades histofoliares'. KUs can be simple if they have only one vascular bundle, or they can be compound if the KUs have more than one vascular bundle.

Vein connection: the longitudinal veins are interconnected by oblique or transversal, short veins. The mesophyll and the parenchyma sheath of the KU can accompany the vascular tissue in its connection.

Vein branching: the longitudinal veins are laterally diverging in short veins, but they do not connect with neighbour veins and end in the mesophyll.

\section{Results}

In all the specimens examined the leaves and stems show some common features. The mesophyll consists of a single layer of cylindrical, radially enlarged, cells that are densely packed, with chloroplasts commonly located peripherally, along the cell walls. The parenchyma sheath is a single layer of cubical cells with large chloroplasts, with respect to those of the mesophyll; chloroplasts are positioned against the internal tangential cell walls (Fig. 1a). The colourless parenchyma is constituted by translucent, large and isodiametric cells, with thin walls; there are few or no chloroplasts.

\section{Leaves}

Leaves of Isostigma are entire, pinnati- or bipinnatisect. The entire leaves can be linear to narrowly ovate with the apex entire (I. herzogii, I. scorzoneraefolium) or briefly bi-tridentate (I. molfinianum), obovate with the apex dentate (I. acaule), or linear, very long with the apex entire or tridentate (I. riedelii, I. simplicifolium). The pinnati- or bipinnatisect leaves have linear (I. crithmifolium, I. dissitifolium, I. speciosum), filiform (I. brasiliense, I. cordobense, I. peucedanifolium) or ovate (I. hoffmannii) leaflets.

All species have amphistomatic leaves. The venation patterns are variable in Isostigma. In I. acaule and I. hoffmannii the veins are reticulate. In I. brasiliense, I. cordobense, I. crithmifolium, I. dissitifolium, I. peucedanifolium, I. riedelii, I. simplicifolium and I. speciosum the pattern in major and minor veins is parallel. In I. herzogii, I. molfinianum and I. scorzoneraefolium the major veins are parallel with only a few connections and branches, but they have smaller veins profusely connected and branched among them (Fig. 4b). 

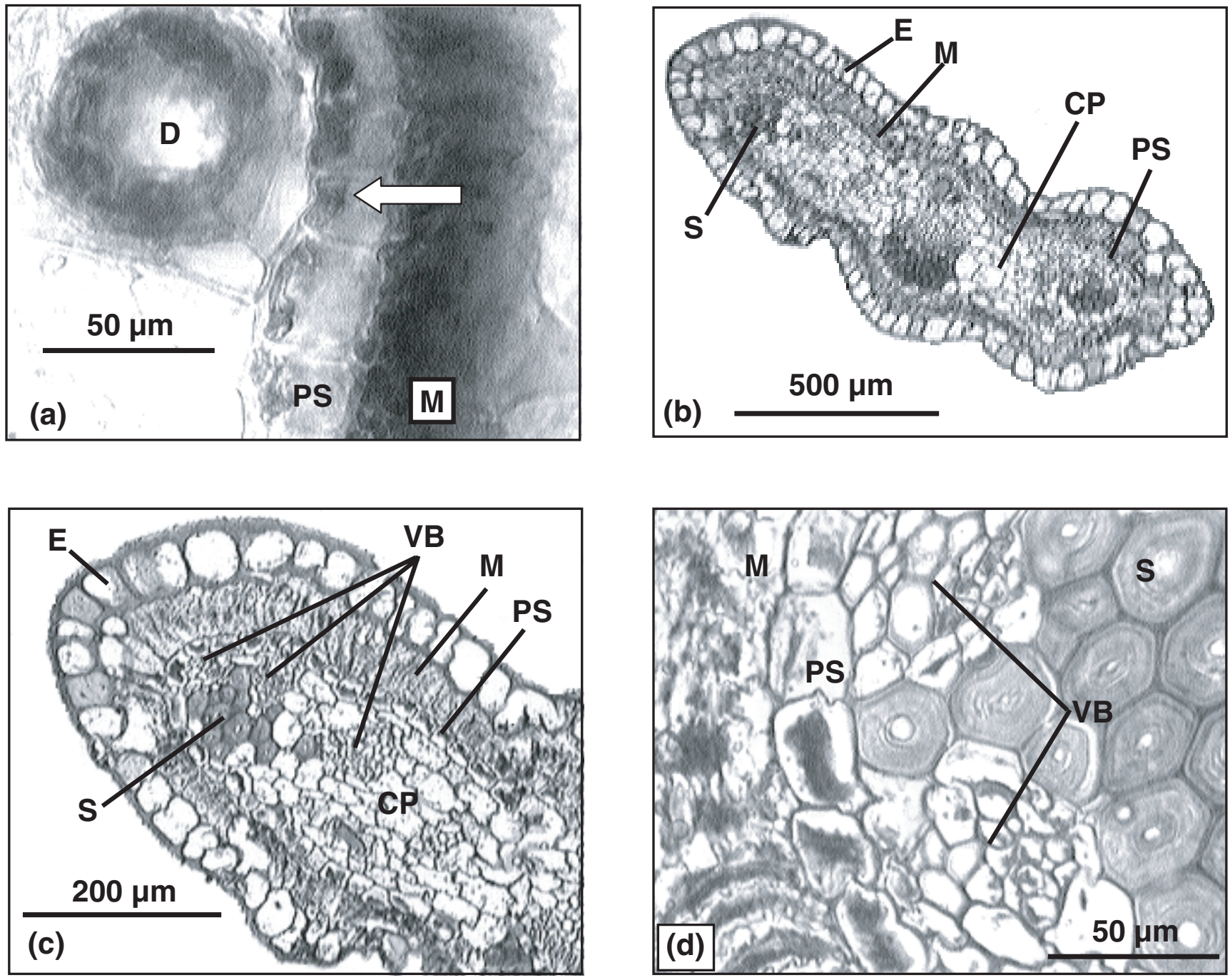

Fig. 1. Light micrographs of cross-section in leaves showing the Eryngiophyllum type: (a) parenchyma sheath with the chloroplasts against the internal tangential cell walls (arrow), note the duct close to the sheath; $(b)$ cross-section of a leaflet showing the epidermis and one KU with the 1-layered mesophyll and parenchyma sheath enclosing several vascular bundles and the internal colourless parenchyma; $(c)$ detail of the leaf margin showing the leaf tissue arrangement; $(d)$ vascular tissue in contact with the parenchyma sheath, note the strands of xylem at both sides of the sclerenchyma. (a) Isostigma speciosum, Dusén 4345 (BM); (b-d) Isostigma crithmifolium, Grassini 340 (BBB). CP = colourless parenchyma, $\mathrm{D}=$ duct, $\mathrm{E}=$ epidermis, $\mathrm{M}=$ mesophyll, $\mathrm{PS}=$ parenchyma sheath, $\mathrm{S}=$ sclerenchyma, $\mathrm{VB}=$ vascular bundle.

All species of Isostigma have Kranz anatomy in their leaves, which can be grouped into two different types: (1) Eryngiophyllum type and (2) Isostigma type. The Eryngiophyllum type was established by Brown (1975) and the Isostigma type is established here.

\section{Eryngiophyllum type (Brown 1975) (Figs 1, 2a, b)}

One Kranz unit per leaf; the KU is compound; sclerenchyma present; veins are not connected (or only one or two connections per leaf) and not branched.

Transection. The $\mathrm{KU}$ encloses three to 11 vascular bundles (Fig. 1b). The photosynthetic mesophyll and the parenchyma sheath are continuous or rarely discontinuous subepidermal layers. The parenchyma sheath is just internal to the mesophyll and in contact with it (Fig. 1c). There is one major, central collateral vascular bundle and one to five lateral, smaller vascular bundles that lie in the colourless internal parenchyma. Bundles of vascular tissue are often in contact with the parenchyma sheath (Fig. 1d). Secretory ducts are also present in the central parenchyma, generally associated to the vascular tissue (Fig. 1a). Sclerenchyma tissue constitutes a continuous sheath around the vascular bundles, or it forms groups near the xylem and the phloem, adjacent to the phloem, or within the colourless parenchyma.

Paradermal. Major vascular bundles run parallel and are embedded in the colourless parenchyma; veins are not 


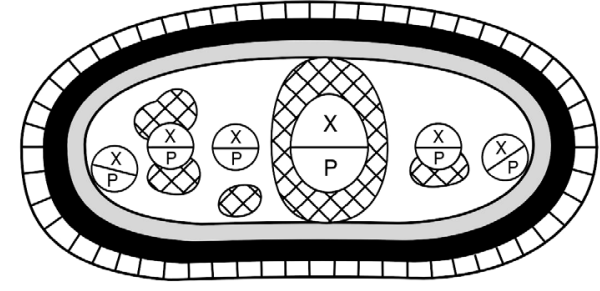

(a)

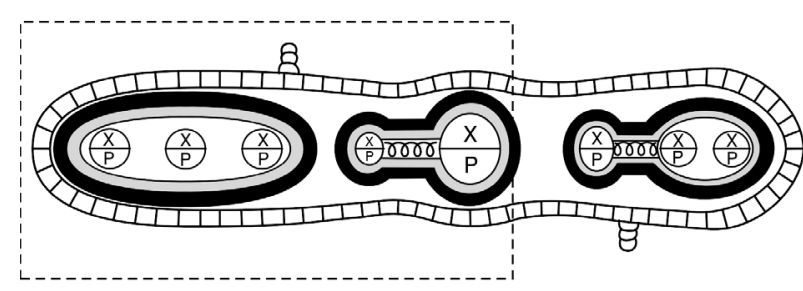

(c)

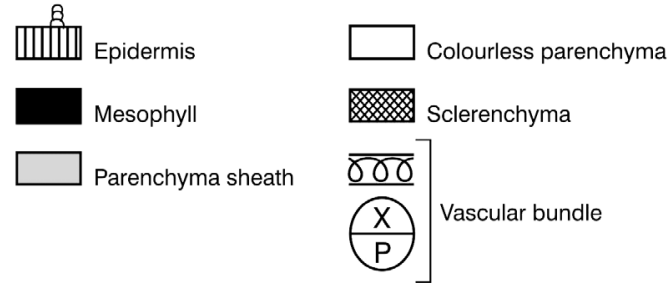

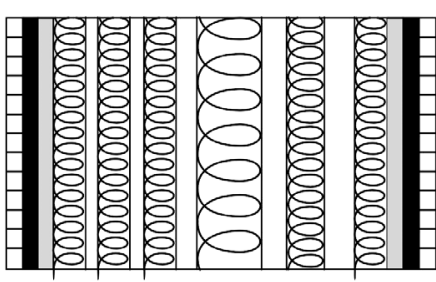

(b)

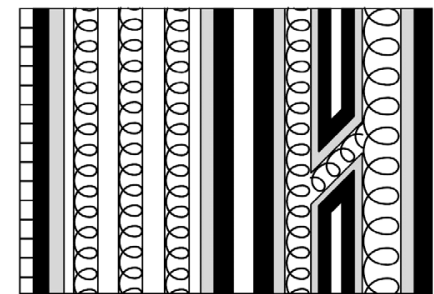

(d)

Delineo $v$ VH Calvetti

Fig. 2. Diagram showing $(a, b)$ the Eryngiophyllum type; $(c, d)$ the Isostigma type. $(a, c)$ Transection, $(b, d)$ paradermal. $\mathrm{P}=$ phloem; $\mathrm{X}=$ xylem; secretory ducts have not been drawn.

branched and lateral connections are generally lacking; when present they are very scarce (only one or two per leaf). Colourless parenchyma is limited by the parenchyma sheath at both sides (Fig. $2 b$ ).

The Eryngiophyllum type is present in Isostigma brasiliense, I. cordobense, I. crithmifolium, I. dissitifolium, I. peucedanifolium, I. riedelii, I. simplicifolium and I. speciosum. Most of these species have continuous layers of both mesophyll and parenchyma sheath, sometimes they are discontinuous at the margins of the leaf and abaxially at the level of the midvein (e.g. some specimens of I. speciosum).

\section{Isostigma type (Figs $2 c$, $d$ and $3 a-e$ )}

More than one KU per leaf; KUs are simple and compound; without sclerenchyma; veins are usually connected and branched.

Transection. This anatomy type has 3-27 KUs per leaf (Fig. 3a). Each KU encloses one to four collateral vascular bundles associated with secretory ducts. Simple and compound KUs coexist in the same transection. Sometimes numerous ducts (c. 12) constitute a ring around the midvein.

Neighbour KUs are commonly connected by vascular tissue, which is accompanied by the mesophyll and the parenchyma sheath (Fig. $3 b-d$ ).

Layers of both mesophyll and parenchyma sheath surround completely the KUs, although in occasions they are interrupted at the abaxial side of the midvein. Some KUs are delimited only by the parenchyma sheath and the mesophyll surrounds two or more KUs (Fig. 3e). Colourless parenchyma is distributed beneath the epidermis and between the KUs when the KUs are simple, inside the KUs when they are compound, or adjacent to the abaxial epidermis. Sclerenchyma tissue is completely absent in this type.

Paradermal. One to four vascular bundles are limited by the parenchyma sheath and mesophyll at both sides. Veins are connected and branched (Fig. 2d).

This type is present in Isostigma acaule, I. herzogii, I. hoffmannii, I. molfinianum and I. scorzoneraefolium. 

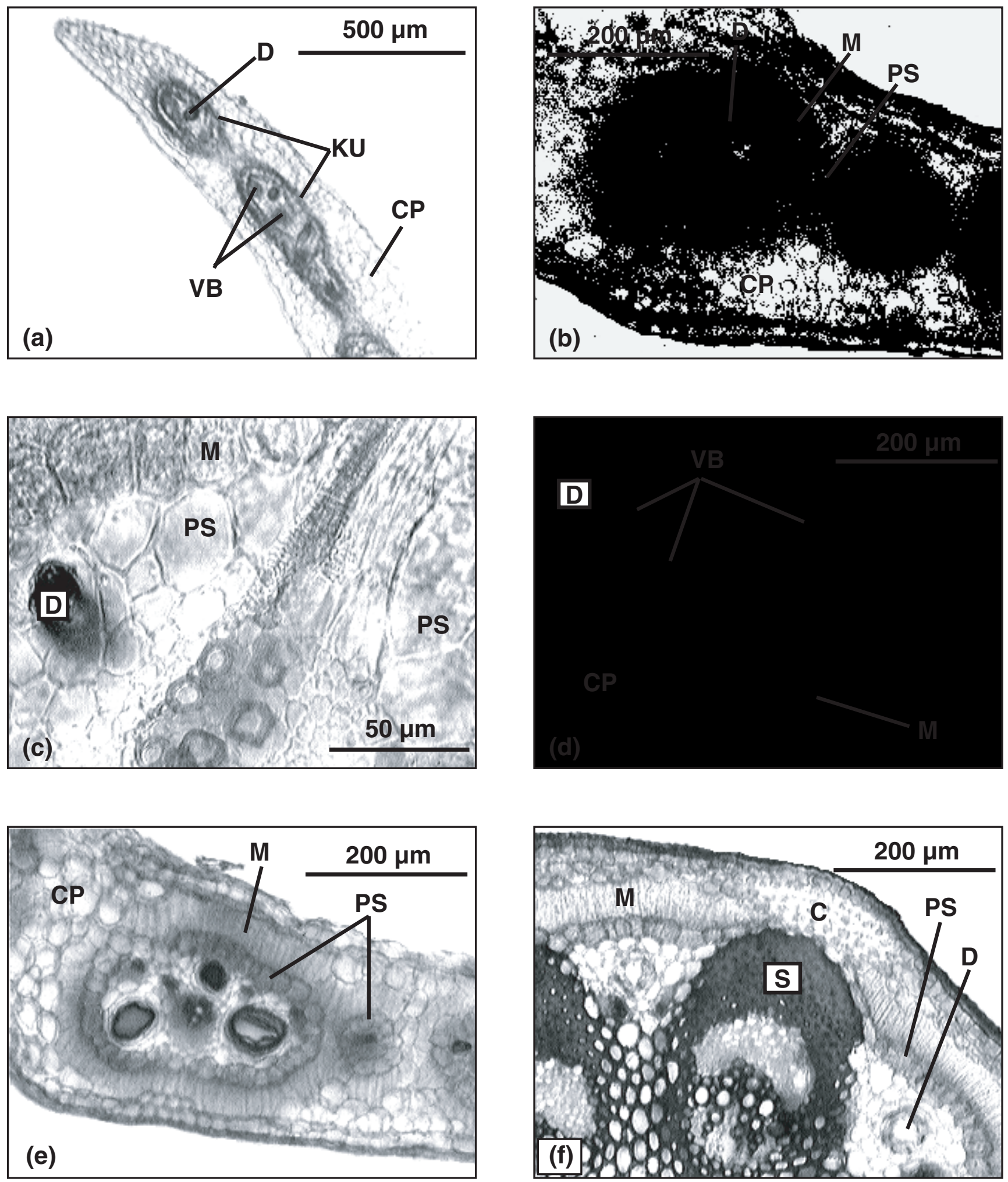

Fig. 3. (a-e) Light micrographs showing the Isostigma type: $(a-c)$ cross-sections in leaves; $(a)$ detail of the leaf margin showing two KUs enclosing several vascular bundles and secretory ducts, the colourless parenchyma surrounds the KUs; note the KU at the right connecting with a third KU; $(b)$ vascular connection between two KUs with its accompanying mesophyll and parenchyma sheath; $(c)$ closer view of the vascular connection; $(d)$ paradermal view of the vascular connections showing the vascular tissue and the mesophyll; the parenchyma sheath can not be seen due to the clearing process; $(e)$ cross-section of leaf showing adjacent veins sharing the mesophyll layer; $(f)$ light micrograph of cross-sections in stem. (a) I. scorzoneraefolium, Malme 3136 (GH); (b, c) I. hoffmannii, Nee 49046 (NY); (d) I. hoffmannii, Ybarrola 2634 (LP); (e) I. herzogii, Herzog $617(\mathrm{G}) ;(f)$ I. dissitifolium, Hassler 6309 (F). C = collenchyma; $\mathrm{CP}=$ colourless parenchyma; $\mathrm{D}=$ duct; KU = Kranz unit; $\mathrm{M}=$ mesophyll; $\mathrm{PS}=$ parenchyma sheath; $\mathrm{S}=$ sclerenchyma; $\mathrm{VB}=$ vascular bundle. 
In I. herzogii, I. molfinianum and I. scorzoneraefolium the amount of connections and branching of veins is variable; in some specimens they are very scarce but in others they are quite abundant. In I. acaule and I. hoffmannii most of the KUs are simple and the compound ones are in the margins.

Stem

All species of Isostigma have Kranz anatomy in their stems, without variation among them.

There are 9-13 collateral vascular bundles bordered by sclerenchyma fibers; each bundle alternates with one secretory duct associated with minor vascular bundles. The major vascular bundles are surrounded by sclerenchyma. Half of them are externally in contact with the ring of parenchyma sheath, followed by the mesophyll. Both parenchyma and mesophyll are single layers that become discontinuous where the subepidermal collenchyma reaches the other half of major vascular bundles (Fig. 3f).

\section{Discussion}

Our findings show that all the species of Isostigma have consistently Kranz anatomy in leaves and stems. The genus Isostigma has developed two different $\mathrm{C}_{4}$ leaf anatomies, distinguished mainly by the number and type of Kranz units

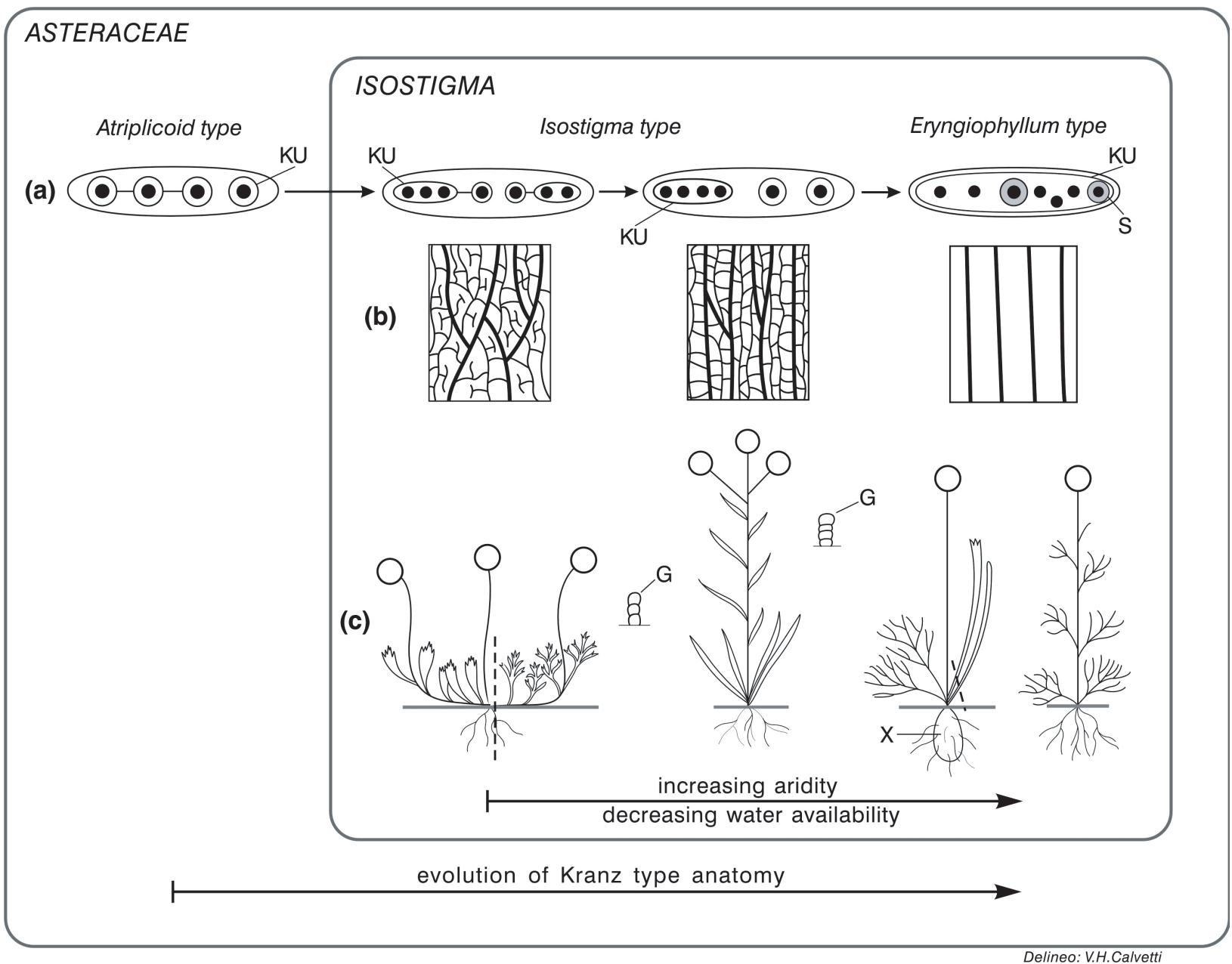

Fig. 4. Hypothesis on the evolution of Kranz anatomy in Asteraceae and in the genus Isostigma associated with other plant features. (a) The Atriplicoid type (e.g. Chrysanthellum indicum var. afroamericanum) with numerous and simple KUs; the Isostigma type with numerous, simple and compound KUs is an intermediate step and the Eryngiophyllum type with only one compound KU and sclerenchyma tissue; (b) change in the patterns of vascularisation from major veins (thick lines) connected and branched (on the left); major veins parallel, with few connections and branches (in the centre); parallel veins scarcely connected and branched (on the right); $(c)$ different habits in Isostigma from hygrophyllous decumbent species with basal, alternate leaves and solitary capitula (on the left); xeric and hygrophyllous species with leaves distributed along the stem and capitula in synflorescenses (in the centre). Both groups of species belong to the Isostigma type and posses glandular hairs. Xeric species belonging to the Eryngiophyllum type, generally with xylopodium, rosulate or distributed leaves without glandular hairs and solitary capitula (on the right). $\mathrm{G}=$ glandular hair; $\mathrm{KU}=\mathrm{Kranz}$ unit; $\mathrm{S}=$ sclerenchyma; $\mathrm{X}=\mathrm{xylopodium}$; the dotted lines represent variation in leaf shapes. 
(KUs) per leaf that range from one compound $\mathrm{KU}$ (Eryngiophyllum type) to several KUs, enclosing one to four veins (Isostigma type).

\section{Kranz types in Asteraceae}

The Eryngiophyllum type has been the only type described exclusively for Asteraceae (Brown 1975), while the Atriplicoid type of Chenopodiaceae has been reported for species of Flaveria and Parthenium (Pyankov et al. 2001). According to the leaf anatomy described by Sánchez et al. (1986) and our own observations, Chrysanthellum indicum var. afroamericanum also corresponds to the Atriplicoid type characterised by a single parenchyma sheath surrounding each vein and the mesophyll arranged radially in relation to the veins. Therefore, the Isostigma type is a new type for Asteraceae.

If we compare the Kranz types of Asteraceae with those of other dicot or monocot families, the Eryngiophyllum type resembles the Kranz-Suaedoid of Chenopodiaceae (Carolin et al. 1975), except that the parenchyma sheath in the former is more closely associated with the veins (Fig. 1d) and the colourless parenchyma replaces the water storage tissue typical of most Chenopodiaceae (Fig. $1 b$ ). There was not found a parallelism between the Isostigma type and other types of $\mathrm{C}_{4}$ anatomy in dicots or monocots.

The Eryngiophyllum type is the most common of the Kranz anatomies in Isostigma, being present in eight of the 13 species. The Isostigma type, on the other hand, occurs in the remaining five species.
In summary, the types of Kranz anatomy established until the present in the Asteraceae are (i) the Eryngiophyllum type in Chrysanthellum, Flaveria, Glossocardia, Isostigma and Pectis, (ii) the Isostigma type in Isostigma and (iii) the Atriplicoid type in Chrysanthellum, Flaveria and Parthenium.

\section{Kranz types and ecology}

Variation in $\mathrm{C}_{4}$ types in relation to ecological patterns was predicted by some authors, e.g. Welkie and Caldwell (1970), Hattersley (1976) and Brown (1977). Accordingly, the two different Kranz anatomies found in Isostigma can be correlated with environmental conditions together with some other plant features (Fig. 4).

The species of Isostigma inhabit six biogeographic provinces in South America, according to the classification of Cabrera and Willink (1980) (Table 1). Table 1 shows that in general the Isostigma type corresponds to species growing in moist places, whereas the Eryngiophyllum type is characteristic of xeric places.

Species of Isostigma with the Eryngiophyllum type are mostly erect, glabrous herbs or subshrubs with solitary capitula and mostly rosulate leaves, that grow under high-light, hot and mostly arid conditions. Most of these species have xylopodium, a tuberous root for water storage (Font Quer 1979). This structure and the centric anatomy in leaves are mechanisms of water-use efficiency, while foliar sclerenchyma prevents tissue damage caused by desiccation (Metcalfe 1983). The close proximity of the continuous mesophyll cell layer to the atmosphere ensures the effective

Table 1. Kranz anatomy, species of Isostigma corresponding to each type, biogeographic provinces and type and characteristics of habitat taken from the literature and label data

Biogeographic provinces correspond to Cabrera and Willink (1980)

\begin{tabular}{|c|c|c|c|}
\hline Species & Biogeographic province & Type of habitat & Habitat characteristics \\
\hline \multicolumn{4}{|c|}{ Isostigma type } \\
\hline I. acaule & Chacoan-Parana & Humid & Parque, swamp, low and modified places; clay soil \\
\hline I. herzogii & Chacoan & $?$ & High field $(600 \mathrm{~m})$ \\
\hline I. hoffmannii & Chacoan-Espinal & Humid & $\begin{array}{l}\text { Pampa, savanna, grassland, open forest; clay or sandy soil but } \\
\text { waterlogged in some seasons }\end{array}$ \\
\hline I. molfinianum & Prepunan & Humid & Marshy places \\
\hline I. scorzoneraefolium & Cerrado & Subhumid-xeric & Open field, grassland, subhumid places; sandy-gravelly soil \\
\hline \multicolumn{4}{|c|}{ Eryngiophyllum type } \\
\hline I. brasiliense & Cerrado & Subhumid?-xeric & Forest clearing, grave beach; sandy soil \\
\hline I. cordobense & Chacoan & Xeric & Low hill \\
\hline I. crithmifolium & Parana-Pampean-Espinal & Xeric & Savanna, dune, gravelly hill, field, sandy, dry and hilly grassland \\
\hline I. dissitifolium & Parana-Chacoan & Xeric & Inculting hill, grassland; sandy and gravelly soil \\
\hline I. peucedanifolium & $\begin{array}{l}\text { Pampean-Parana- } \\
\text { Cerrado-Chacoan }\end{array}$ & Subhumid?-xeric & $\begin{array}{l}\text { Open and high field, sunny slope, gravelly hill, cerrado, } \\
\text { gallery forest, grassland, savanna, fixed dunes, } \\
\text { palm grove, ravine; sandy, clay, gravelly and dry soil }\end{array}$ \\
\hline I. riedelii & Parana & Subhumid-xeric & $\begin{array}{l}\text { Cerrado scrub and cerrado forest, dry and subhumid field, slopes and } \\
\text { hill near river; sandy soil }\end{array}$ \\
\hline I. simplicifolium & Cerrado & Xeric & Cerrado scrub and cerrado forest, field; sandy soil \\
\hline I. speciosum & Cerrado-Parana & Xeric & Dry field, cerrado forest and cerrado scrub \\
\hline
\end{tabular}


assimilation of atmospheric $\mathrm{CO}_{2}$ (Ehleringer and Monson 1993) and high-light use. The colourless parenchyma in the leaf center can be seen as another water-storage system of the plants and it is important in the hydric economy.

Species with the Isostigma type of Kranz anatomy have sparse glandular hairs, lack sclerenchyma tissue completely and grow mostly in humid places. The presence of more than one KU per leaf in the Isostigma type led to a re-arrangement of the leaf tissues when compared with the Eryngiophyllum type. The mesophyll and the parenchyma sheaths are not continuous and are not completely adjacent to the epidermis. The colourless parenchyma surrounds the KUs or, less commonly, lies inside the major KUs. This changed tissue arrangement should not be as efficient in light and water use as that of Eryngiophyllum type, probably because the habitat conditions are not so harsh. The lack of sclerenchyma also suggests that the species with this type of Kranz anatomy are not so exposed to periods of desiccation.

Within the Isostigma type, some species (I. acaule, I. hoffmannii) are decumbent herbs inhabiting humid places, with solitary capitula and leaves present only at the point of contact between the stem and the soil, otherwise the stems are sparsely bracteolate (Fig. 4). All the specimens examined of these two species showed abundant vein branching and connection. Other species (I. herzogii, I. molfinianum, I. scorzoneraefolium) are erect herbs or subshrubs with corymbose synflorescences and leaves spreading along the stems and grow in humid to xeric habitats. Some of the examined specimens showed scarce vascular connections and branching in their major veins. These differences in the venation pattern in species with Isostigma type would suggest a correlation between an increase in vein branching and connection and humid habitats. This correlation has been reported in other $\mathrm{C}_{4}$ genera such as Echinochloa (Poaceae) (A. M. Arambarri, pers. comm.).

\section{Kranz types and evolution}

Framing the different leaf Kranz anatomies analysed here in an evolutionary scenario, it can be hypothesised that species of Isostigma changed the use of a 'hose' to a 'water tank' or, in other words, the replacement of vascular connections in species of humid and mesic places by central colourless parenchyma to increase the water-use efficiency in species of arid places (Fig. 4). The correlation between the specialisation in leaf anatomy and the habitat of limited water availability was already pointed out by Welkie and Caldwell (1970) for other dicot families with $\mathrm{C}_{4}$ species.

According to Brown (1975), the continuous parenchyma sheath of the Eryngiophyllum type may have evolved by all adjacent bundle sheaths becoming continuous by lateral bundle sheath extensions (similar to those of the Isostigma type) followed by filling the interior with massive colourless parenchyma. The Atriplicoid type, present in some genera of Asteraceae, with its numerous, simple KUs, could be the starting point of such sequence, the numerous, simple and compound KUs of the Isostigma type being the intermediate stepping stone, to reach the unique, compound $\mathrm{KU}$ of the Eryngiophyllum type.

The following three main lines of evidence led us to suggest a sequence from the Atriplicoid to the Eryngiophyllum type: (1) ontogeny; (2) similar processes in other plant families; and (3) historical biogeography. First, it was postulated (Brown 1975; Soros and Dengler 2001) that the parenchyma sheaths originate from the same procambium that develops into the vascular bundles. Following this, the evolutionary sequence in Asteraceae could start from the Atriplicoid type, with various independent parenchyma sheaths surrounding each vascular bundle and then fussing (Isostigma type) to end in the Eryngiophyllum type with its unique, continuous layer enclosing all the bundles. The opposite sequence, i.e. from the Eryngiophyllum to the Atriplicoid type, would be more complex, since it would involve various sheaths fussing into a unique layer and then splitting again into various sheaths to surround each bundle. Second, other plant families such as Chenopodiaceae seem to have followed a similar sequence (Carolin et al. 1975) where various, independent arcs of partial parenchyma sheath and mesophyll (Kochioid type) derived into complete layers of Kranz cells and mesophyll surrounding the vascular bundles (Salsoloid type). Third, there was a change from humid to xeric environments in the climatic history of southern South America at the time of the early evolution of Asteraceae. These changes greatly affected the biota of the area, which had to adjust to the arid conditions.

It was hypothesised that occurrence of $\mathrm{C}_{4}$ photosynthesis in Dicotyledonae appeared recently in geological time, possibly in response to the depleted atmospheric $\mathrm{CO}_{2}$ levels of the late Miocene and the Quaternary (Ehleringer et al. 1997). During the Miocene (25-5 million years ago), floristic assemblages analogous to the actual types of subtropical and temperate forest rose in southern South America (Villagrán and Hinojosa 1997), with savanna-grassland vegetation covering part of north-eastern Argentina, Uruguay and southern Brazil. Miocene could be the period of appearance of taxa with the Atriplicoid type of Kranz anatomy. During the Pliocene (5-1 million years ago), the distribution of this flora was fragmented and xeric formations expanded. The uplift of the Andes created the extremely dry Chaco and Monte. During Pleistocene, local glaciation resulted in a series of adjustments that resulted in numerous speciation events within genera (Stuessy et al. 1996). Pleistocenic events in the Quaternary, with their series of humid and arid phases (Haffer 1969; Hammen 1974; Simpson 1975), were fundamental in the biotic history of South America (Katinas et al. 1999; Katinas and Crisci 2000). During arid phases the xeric forms were favoured for migration and establishment, and mesic forms were isolated 
in refugia and evolved there. Isolation favoured the evolution of new species of the mesic forms during the dry phases. During humid phases the opposite occurred. Xeric species became isolated in dry refugia and further speciated, while the mesic species dispersed and became established in a wider range until the next stage in the cycle of climatic change. This model, proposed for the Neotropical CAM Bromeliaceae (Gilmartin 1983) could also explain the current $\mathrm{C}_{4}$ types in species of Isostigma inhabiting either wet (Isostigma type) or dry habitats (Eryngiophyllum type).

In conclusion, diversity in habit, morphological adaptive features and habitat, seems to be correlated with the different Kranz types in Isostigma. Further studies including all the genera of the Chrysanthellum group in a phylogenetic framework will allow a more comprehensive evaluation of the evolution of Kranz anatomy in this complex.

\section{Acknowledgments}

We thank Ana Arambarri and Nancy Dengler for critical reading of the manuscript and two anonymous reviewers for their valuable suggestions. Curators of herbaria for loan of specimens and Victor H. Calvetti for delineating Figs 2 and 4 are also acknowledged. This work was supported by Consejo Nacional de Investigaciones Científicas y Técnicas (CONICET) and Universidad Nacional del Sur (UNS).

\section{References}

Araus JL, Brown RH, Bouton JH, Serret MD (1990) Leaf anatomical characteristics in Flaveria trinervia $\left(\mathrm{C}_{4}\right)$, Flaveria brownii $\left(\mathrm{C}_{4}\right.$-like $)$ and their $\mathrm{F}_{1}$ hybrid. Photosynthesis research 26, 49-57.

Björkman O (1973) Comparative studies on photosynthesis in higher plants. Photophysiology 8, 1-63.

Brown WV (1975) Variations in anatomy, associations, and origins of Kranz tissue. American Journal of Botany 62, 395-402.

Brown WV (1977) The Kranz syndrome and its subtypes in grass systematic. Memoirs of the Torrey Botanical Club 23, 1-97.

Cabrera AL (1959) Ocho compuestas sudamericanas nuevas. Notas del Museo de La Plata 19, 202-204.

Cabrera AL, Willink A (1980) 'Biogeografía de América Latina (2nd edn).' (The general Secretariat of the Organization of American States: Washington, DC)

Carolin RC, Jacobs SWL, Vesk M (1975) Leaf structure in Chenopodiaceae. Botanische Jahrbücher für Systematik, Pflanzengeschichte und Pflanzengeographie 95, 226-255.

Carolin RC, Jacobs SWL, Vesk M (1978) Kranz cells and mesophyll in the Chenopodiales. Australian Journal of Botany 26, 683-698.

Dengler NG, Nelson T (1999) Leaf structure and development in $\mathrm{C}_{4}$ plants. In ' $\mathrm{C}_{4}$ plant biology'. (Eds RF Sage, RK Monson) pp. 133-172. (Academic Press: New York, London)

Ehleringer JR, Monson RK (1993) Evolutionary and ecological aspects of photosynthetic pathway variation. Annual Review of Ecology and Systematics 24, 411-439.

Ehleringer JR, Cerling TE, Helliker BR (1997) $\mathrm{C}_{4}$ photosynthesis, atmospheric $\mathrm{CO}_{2}$, and climate. Oecologia 112, 285-299.

Fisher DD, Jochen Schenk H, Thorsch JA, Ferren Jr WR (1997) Leaf anatomy and subgeneric affiliations of $\mathrm{C}_{3}$ and $\mathrm{C}_{4}$ species of Suaeda (Chenopodiaceae) in North America. American Journal of Botany 84, 1198-1210.
Font Quer P (1979) 'Diccionario de Botánica.' (Editorial Labor: Barcelona)

Gilmartin AJ (1983) Evolution of mesic and xeric habitats in Tillandsia and Vriesea (Bromeliaceae). Systematic Botany 8, 233-242.

Haberlandt G (1882) Vergleichende Anatomie des Assimilatorischen Gewebesystems der Pflanzen. Jahrbücher für wissenschaftliche Botanik 13, 74-188.

Haberlandt G (1914) 'Physiological plant anatomy.' (Macmillan: London)

Haffer J (1969) Speciation in Amazonian forest birds. Science 165, 131-137.

Hammen T (1974) Pleistocene changes of vegetation and climate in tropical America. Journal of Biogeography 1, 3-26.

Hattersley PW (1976) 'Speciation and functional significance of the leaf anatomy of $\mathrm{C}_{4}$ plants.' (Australian National University: Canberra)

Holmgren PK, Holmgren NH, Barnett LC (1990) 'Index herbariorum. Part 1: the herbaria of the world (8th edn).' (International Association for Plant Taxonomy by New York Botanical Garden: Bronx, NY)

Johnson SC, Brown WV (1973) Grass leaf ultrastructural variations. American Journal of Botany 60, 727-735.

Karis PO, Ryding O (1994) Tribe Heliantheae. In 'Asteraceae: cladistics and classification'. (Ed. K Bremer) pp. 559-624. (Timber Press: Portland, OR)

Katinas L, Crisci JV (2000) Cladistic and biogeographic analyses of the genera Moscharia and Polyachyrus (Asteraceae, Mutiseae). Systematic Botany 25, 33-46.

Katinas L, Morrone JJ, Crisci JV (1999) Track analysis reveals the composite nature of the Andean biota. Australian Journal of Botany 47, 111-130.

Kellogg EA (1999) Phylogenetic aspects of the evolution of $\mathrm{C}_{4}$ photosynthesis. In ' $\mathrm{C}_{4}$ plant biology'. (Eds RF Sage, RK Monson) pp. 411-444. (Academic Press: New York, London)

Metcalfe CR (1983) Ecological anatomy and morphology general survey. In 'Anatomy of dicotyledons (2nd edn), Vol. 2'. (Eds CR Metcalfe, L Chalk) pp. 126-156. (Clarendon Press: Oxford)

Moore BD, Franceschi VR, Cheng S, Jingrui W, Ku MSB (1987) Photosynthetic characteristics of the $\mathrm{C}_{3}-\mathrm{C}_{4}$ intermediate Parthenium histerophorus. Plant Physiology 85, 984-989.

Petenatti EM, Del Vitto LA (2000) Estructura Kranz en las especies argentinas de Flaveria (Asteraceae-Helenieae). Kurtziana 28, 251-257.

Peter G (2001) Anatomía foliar de Isostigma crithmifolium (Asteraceae, Heliantheae). Boletín de la Sociedad Argentina de Botánica 36 (Suplemento), 26.

Pyankov V, Ziegler H, Kuz'min A, Edwards G (2001) Origin and evolution of $\mathrm{C}_{4}$ photosynthesis in the tribe Salsoleae (Chenopodiaceae) based on anatomical and biochemical types in leaves and cotyledons. Plant Systematics and Evolution 230, 43-74.

Ryding O, Bremer K (1992) Phylogeny, distribution, and classification of the Coreopsideae (Asteraceae). Systematic Botany 17, 649-659.

Sage RF, Li M, Monson RK (1999) The taxonomic distribution of $\mathrm{C}_{4}$ photosynthesis. In ' $\mathrm{C}_{4}$ plant biology'. (Eds RF Sage, RK Monson) pp. 551-584. (Academic Press: New York, London)

Sánchez E, Arriaga MO, Panarello HO (1986) El síndrome de 'Kranz' en Asteraceae de la flora argentina. Boletín de la Sociedad Argentina de Botánica 24, 249-259.

Sánchez E, Arriaga MO, Panarello HO (1987) El síndrome de Kranz en tallos de Chrysanthellum (Asteraceae). Boletín de la Sociedad Argentina de Botánica 25, 123-129.

Sarmiento MNR de, Israilev LRA de, Seeligman P (1989) El síndrome de Kranz en Pectis sessiliflora y Pectis odorata y su probable importancia como marcador filogenético y evolutivo. Lilloa 37, $15-18$. 
Sarmiento MNR de, Mendiondo ME, Abdala LA (1995) Síndrome de Kranz en especies de la tribu Tageteae (Asteraceae). Lilloa 38, 167-168.

Schöch E (1971) Malat und Aspartat als Hauptprodukte der $\mathrm{CO}_{2}$-Kurzzeit Fixierung nun auch bei einer Composite. Zeitschrift für Pflanzenphysiologie 64, 367-368.

Schwabe H (1961) Glicol de etilene: un nuevo método en histología para ablandar material de herbario. Boletín de la Sociedad Argentina de Botánica 9, 393-394.

Sherff EE (1926) Revision of the genus Isostigma Less. Botanical Gazette 81, 241-257.

Sherff EE (1931) New or otherwise noteworthy Compositae. VI. Botanical Gazette 91, 308-314.

Simpson B (1975) Pleistocene changes in the flora of the high tropical Andes. Palaeobiology 1, 273-294.

Smith BN, Turner BL (1975) Distribution of Kranz syndrome among Asteraceae. American Journal of Botany 62, 541-545.

Soros CL, Dengler NG (2001) Ontogenetic derivation and cell differentiation in photosynthetic tissues of $\mathrm{C}_{3}$ and $\mathrm{C}_{4}$ Cyperaceae. American Journal of Botany 88, 992-1005.

Strittmatter CGD de (1973) Nueva técnica de diafanización. Boletín de la Sociedad Argentina de Botánica 15, 126-129.
Stuessy TF, Sang T, DeVore ML (1996) Phylogeny and biogeography of the subfamily Barnadesioideae with implications for early evolution of the Compositae. In 'Compositae: systematics, vol. 1'. Proceedings of the international Compositae conference. (Eds DJN Hind, HJ Beentje) pp. 463-490. (Royal Botanic Gardens: Kew)

Turner BL (1988) Taxonomic study of Chrysanthellum (Asteraceae, Coreopsideae). Phytologia 64, 410-444

Villagrán C, Hinojosa LF (1997) Historia de los bosques del sur de Sudamérica, II: análisis fitogeográfico. Revista Chilena de Historia Natural 70, 241-267.

Welkie GW, Caldwell M (1970) Leaf anatomy of species in some dicotyledon families as related to the $\mathrm{C}_{3}$ and $\mathrm{C}_{4}$ pathways of carbon fixation. Canadian Journal of Botany 48, 2135-2146.

Zuloaga F, Morrone O, Dubcovsky J (1989) Exomorphological, anatomical, and cytological studies in Panicum validum (Poaceae: Panicoideae: Paniceae): its systematic position within the genus. Systematic Botany 14, 220-230.

Manuscript received 26 September 2002, accepted 7 February 2003

Appendix. Collection data (country, province, locality, date of collection, collector and number and herbarium abbreviation) of the specimens analysed of Isostigma and Chrysanthellum

Names of the Herbaria are abbreviated according to Index Herbariorum (Holmgren et al. 1990)

Isostigma acaule (Baker) Chodat: Paraguay, Dept Central, near Ypané, 16.xi.1969, Pedersen 9317 (LP); Paraguay, Dept Presidente Hayes, Jardín Botánico, xi.1939, Rojas 8704 (LP); Paraguay, Dept Presidente Hayes, Trinidad, Parque Botánico, bañados del río Paraguay, viii.1916, Rojas 1683b (LP); Paraguay, in campo Tacuaral, 1897, Hassler 3811 (BM, NY).

I. brasiliense (Gardner) Benth. \& Hook.: Brazil, State Minas Geraes, Uberaba, 18.xii.1848, Regnell 783 (F); Brazil, State Minas Geraes, Municipio Ithintal, Carral, 15.x.1950, Macedo 2627 (US).

I. cordobense Cabrera: Argentina, Prov. Córdoba, Dept. Colón, Saldán, lomas frente al balneario San Remo, 22.xi.1964, Ariza Espinar 1969 (CORD, LP).

I. crithmifolium Less.: Argentina, Prov. Corrientes, Dept. Ituzaingó, ruta 39, a 10 km de Ruta 14, 11.ii.1978, Cabrera \& Sáenz 29101 (LP); Argentina, Prov. Corrientes, Dept. not located, Río Mocoretá, 20.i.1995, Long 664 (BBB); Argentina, Prov. Entre Ríos, Dept Colón, Parque Nacional del Palmar, roquerío frente a La Glorieta, 20.xii.1986, Xifreda \& Maldonado 600 (LP); Argentina, Prov. Entre Ríos, Dpto Federación, Costa Lago Salto Grande, campo Zampedri, Cnia. Susanche Sauce, 3.i.1999, Grassini 340 (BBB); Argentina, Prov. Entre Ríos, Dept not located, Costa Río Uruguay, 20.xii.1961, Gamerro 1146 (LP); Brazil, State Rio Grande do Sul, Quaraí, Estancia do Jardín, in campo, i.1945, Rambo 26022 (LP); Paraguay, Dept. Misiones, Santiago, Estancia 'La Soledad', 27.xii.1965, Pedersen 7682 (LP); Uruguay, Dept Paysandú, limestone country north of Quebracho, 9.xii.1943, Bartlett 21138 (LP); Uruguay, Dept not located, Río Uruguay y arroyo Chapicuy, 21.ii.1941, Rosengurtt B-3210 (LP).

I. dissitifolium Baker: Paraguay, Dept La Cordillera, Cordillera Central, Cerros de Tobatí, ix.1902, Hassler 6309 (F); Paraguay, Dept La Cordillera, Cordillera de los Altos, xi.1902, Fiebrig 450 (F).

I. herzogii Hassl.: Bolivia, Dept Santa Cruz, Santiago de Chiquitos, v.1907, Herzog 617 (G).

I. hoffmannii Kuntze: Argentina, Prov. Corrientes, Dept Lavalle, ruta 12 km 753, 27.ii.1961, Pedersen 5821 (LP); Argentina, Prov. Corrientes, Dept Mercedes, cercanías de Justino Solari, 10.iii.45, Ybarrola 2634 (LP); Bolivia, Dept Santa Cruz, Pampa de Sta. Cruz, i.1911, Herzog 1309 (LP); Bolivia, Dept Santa Cruz, Prov. Andrés Ibáñez, $17^{\circ} 55^{\prime} \mathrm{S}, 63^{\circ} 15^{\prime} \mathrm{W}$, 18.iv.1998, Nee 49046 (NY).

I. molfinianum Sherff: Argentina, Prov. Catamarca, 1.ii.1910, Spegazzini 33306 (F); Argentina, Prov. La Rioja, Dept Chilecito, Cuesta de Catinzaco, 30.i.1906, Kurtz 13369 (CORD); Argentina, Prov. La Rioja, Dept Rosario Vera Peñaloza, Quebrada Totoral, ii.1896, Kurtz 9025 (LP).

I. peucedanifolium (Spreng.) Less.: Brazil, State Mato Grosso, Mun. Chapada dos Guimaraes, Capao Seco, 15.xi.1975, Hatschbach 37591 (LP); Brazil, State Sao Paulo, Campinas, fazenda do Campo Grande, 13.i.1940, Lima 5312 (SP); Uruguay, Dept Artigas, Artigas, i.1936, Chebataroff 1998 (LP).

I. riedelii Sch.Bip.: Paraguay, Dept Amambay-Caaguazú, Sierra de Amambay, xii.1907/1908, Hassler 9927 (F); Paraguay, Dept Itapúa, Colonia Gral. Delgado, Estancia San Miguelito, 12.xi.1956, Pedersen 4271 (LP); Paraguay, Dept not located, 'in regione cursus superioris fluminis Apa', xi.1901/1902, Hassler 8047 (F).

I. scorzoneraefolium (Baker) Sherff: Brazil, State Mato Grosso, Cuiabá, 26.iv.1903, Malme $3136(\mathrm{GH})$; Brazil, State Mato Grosso, entre Morinho y Coxipó, pr. Cuiabá, 26.iv.1894, Malme 1584 (BM)

I. simplicifolium Less.: Brazil, State Minas Geraes, 1840, Claussen s/n (BM 632486).

I. speciosum Less.: Brazil, State do Café, km 70 PM, 7.ii.1965, Dombrowski 1474 (LP); Brazil, State Mato Grosso, Capao Grande, 7.iii.1904, Dusén 4345 (BM).

Chrysanthellum indicum DC. var. afroamericanum B.L.Turner: Argentina, Prov. Córdoba, Dept. Pocho, Pampa de Pocho, 8.iv.1950, Hunziker 8353 (LP); Argentina, Prov. Jujuy, Dept Capital, El Cucho, 21.i.1971, Fabris 8179 (LP); Argentina, Prov. San Luis, Sas. de San Luis, El Telón, i.1907, Baez s/n (LP 069426). 